\title{
ANALISIS KINERJA KEUANGAN SEBELUM DAN SESUDAH AKUISISI PADA PERUSAHAAN YANG TERDAFTAR DI BURSA EFEK INDONESIA (PERIODE 2011 - 2016)
}

\author{
Meindro Waskito \\ Dewi Hidayat \\ Fakultas Ekonomi dan Bisnis Program Studi Manajemen \\ Universitas Islam As-Syafi'iyah \\ meindro.waskito@gmail.com
}

\begin{abstract}
The purpose of this research to determine the difference between the financial performance before and after the acquisition of a nonfinancial company listed on the Indonesia Stock Exchange using which is proxied with the ratio of finance current ratio, total assetsturn over, return on equity, debt to equity ratio, earnings per share.The research period used is 2011-2016.The population in this study are companies that do acquisitions listed on the BEI. The sample selection of this research using non probability sampling techniques, with purposive sampling approach. The sample size is 17 samples. The data used are secondary data. Tests conducted are descriptive statistical test, normality test, and test wilcoxon signed rank test. The data analysis used to test the hypothesis is by using paired sample analysis differentiation technique. Based on the result of research indicate that there were significant differences in total assets turnover, return on equity and earnings per share, while the current ratio and debt to equit ratio did not have a significant difference between before and after the acquisition.
\end{abstract}

Keywords: Financial Performance, Acquisition, Current Ratio, Total Assets Turnover, Return on Equity, Debt to Equity Ratio, Earnings per Share

\begin{abstract}
Abstrak : Penelitian ini bertujuan untuk mengetahui perbedaan kinerja keuangan antara sebelum dan sesudah akuisisi pada perusahaan yang terdaftar di Bursa Efek Indonesia yang diproksikan dengan current ratio, total assetsturn over, return on equity, debt to equity ratio, earnings per share. Periode penelitian yang digunakan adalah tahun 2011 2016. Populasi pada penelitian ini adalah perusahaan yang melakukan akuisisi yang terdaftar di BEI. Pemilihan sampel dalam penelitian ini menggunakan teknik non probability sampling, dengan pendekatan purposive sampling. Jumlah sampel penelitian sebanyak 17 sampel. Data yang digunakan yaitu data sekunder. Pengujian yang dilakukan adalah uji statistik deskriptif, uji normalitas, dan uji wilcoxon signed rank test. Analisis data yang digunakan untuk menguji hipotesis adalah dengan menggunakan teknik analisis uji beda sampel berpasangan. Berdasarkan hasil penelitian menunjukan bahwa terdapat perbedaan yang signfikan pada total assetsturn over, return on equity dan earnings per share sedangkan pada current ratio dan debt to equit ratio tidak memiliki perbedaan yang signifikan antara sebelum dan sesudah akuisisi.
\end{abstract}

Kata Kunci: Kinerja Keuangan, Akuisisi, Current Ratio, Total Assets Turnover, Return on Equity,Debt to Equity Ratio, Earnings per Share. 


\section{PENDAHULUAN}

\subsection{Latar Belakang}

Persaingan yang semakin ketat di dunia usaha menuntut setiap perusahaan untuk bertahan pada setiap kondisi, serta bisa berkembang dan berdaya saing tinggi. Hal ini bisa diwujudkan dengan cara perusahaan dapat memilih serta mengembangkan strateginya. Strategi bersaing perusahaan untukdapat mengembangkan perusahaannya harus sesuai dengan ukuran perusahaan serta tujuan jangka panjang perusahaan. Strategi dapat dilakukan dengan cara memperluas kegiatan perusahaan yang sudah ada, misalnya saja dengan menambah jumlah atau variasi produk, membangun perusahaan baru ataupun dengan membeli perusahaan lain (Aprilianti, 2017).

Salah satu strategi yang dapat dilakukan oleh perusahaan agar perusahaan bisa bertahan atau bahkan berkembang adalah dengan melakukan akuisisi.Menurut Hariyani dkk (2011:22) Akuisisi adalah pengambilalihan suatu perusahaan dengan cara membeli saham mayoritas perusahaan sehingga menjadi pemegang saham pengendali tetapi dalam peristiwa akuisisi baik perusahaan yang mengambil alih (pengakuisisi) maupun perusahaan yang diambil alih (diakuisisi) tetap hidup sebagai satu badan hukum yang terpisah. Sedangkan menurut Kamaludin dkk (2015:16)Akuisisi adalah upaya pengambilalihan kepemilikan suatu perusahaan oleh perusahaan lain yang dilakukan dengan cara membeli sebagian atau seluruh saham perusahaan, dimana perusahaan yang diambil alih tetap memiliki badan hukum sendiri dengan maksud untuk meningkatkan pertumbuhan usaha.

Fenomena akuisisi di Indonesia sudah tidak asing lagi bagi perusahaan yang sudah berkembang, jumlah akuisisi pun selalu mengalami peningkatan dalam beberapa tahun terakhir ini. Komisi Pengawas Persaingan Usaha (KPPU) mencatat peningkatan jumlah notifikasi akuisisi pada tahun 2013 dan 2014 lebih tinggi dibandingkan dengan tahun 2011 dan 2012. Dimana pada tahun tersebut kondisi perekonomian Indonesia berada dalam kondisi terpuruk, karena dipengaruhi oleh perekonomian dunia yang cenderung tidak stabil. Penyebabnya adalah kenaikan harga minyak dunia yang mendorong subsidi membengkak serta merosotnya nilai tukar rupiah terhadap dolar yang melipatgandakan nilai utang luar negeri (Sumber: http://merdeka.com)sehingga terdapat banyak pelaku usaha melakukan aktivitas akuisisi untuk tetap mempertahankan eksistensi perusahaannya.

Menurut catatan KPPU pada tahun 2011 total nilai aktivitas akuisisi sebesar US\$ 6,8 milyar sedangkan pada tahun 2012 sebesar US\$ 477 juta. Turunnya nilai transaksi akuisisi di tahun 2012 disebabkan perlambantan ekonomi global dan mengakibatkan berbagai penghambatan aktivitas akuisisi di tahun 2012. Namun, rebound pertumbuhan PDB global yang terjadi ditahun 2013 memunculkan optimisme akan perbaikan ekonomi. Pada tahun 2013, total nilai akuisisi meningkat 77\% dari transaksi diatas sebesar US\$ 10 milyar sedangkan pada tahun 2014 total nilai akuisisi mengalami penurunan dari tahun 2013 dengan nilai transaksi US\$ 9 miliar, penurunan tersebut disebabkan oleh beberapa faktor salah satunya dipicu oleh dampak Pemilu 2014 yang membuat sejumlah investor wait \& see hingga kondisinya stabil. Alasan lainnya, banyak keputusan pemerintah yang membuat aksi akuisisi sempat terhenti. Seperti aturan mengenai pembatasan kepemilikan asing dalam jasa pengeboran minyak dan gas (migas), baik onshore (di atas tanah) maupun offshore (di atas laut). (Sumber: http://marketeers.com).

Selama kurun waktu dua tahun terakhir, Komisi Pengawasan Persaingan Usaha (KPPU) telah mencatat puluhan notifikasi akuisisi. Terutama setelah berlakunya Peraturan Pemerintah Nomor 57 Tahun 2010 Tentang Penggabungan atau Peleburan 
Badan Usaha dan Pengambilalihan Saham Perusahaan yang Dapat Mengakibatkan Terjadinya Praktik Monopoli dan Persangian Usaha Tidak Sehat ("PP 57/2010"). Bahkan, secara kuantitas jumlah aktivitas akuisisi semakin bertambah seiring dengan laju pertumbuhan ekonomi.

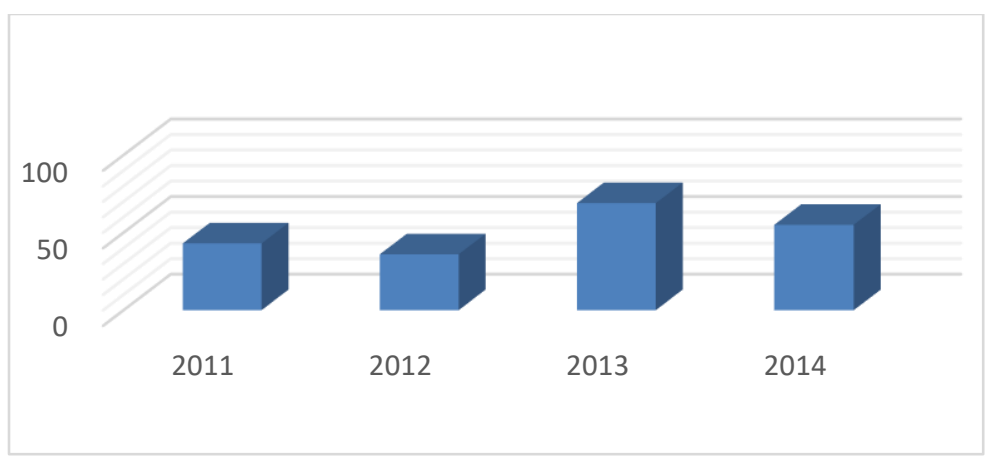

(Sumber: Komisi Pengawas Persaingan Usaha (KPPU)

\section{Gambar : Jumlah Perusahaan Yang Melakukan Akuisisi Tahun 2011-2014}

Gambar menunjukan jumlah perusahaan yang melakukan akuisisi pada tahun 20112014. Pada tahun 2011 terdapat 43 perusahaan yang melakukan akuisisi sedangkan pada tahun 2012 terdapat 36 perusahaan yang melalukan akuisisi lalu pada tahun 2013 notifikasi akuisisi meningkat menjadi 69 perusaahan yang melakukan akuisisi dan menurun pada tahun 2014 menjadi 55 perusahaan.

Salah satu contoh perusahaan yang berhasil meningkatkan pendapatannya dari aktivitas akuisisi yaitu PT Bernakat Integra Tbk (BIPI) yang mengakuisisi perusahaan jasa pertambangan yakni PT Astrindo Mahakarya Indonesia (AMI) yang dibeli dari Reliance Assets Holding Corp (RAH) senilai US\$ 567 juta. Akuisisi ini menimbulkan pendapatan BIPI di tahun 2013 naik menjadi 5 kali lipat dari jumlah US\$ 38 juta menjadi US\$ 190 juta, dari peningkatan pendapatan ini BIPI alami pertumbuhan laba yang sangat signifikan dari sebelumnya hanya US\$ 929 ribu menjadi US\$ 55 juta. Berbeda dari PT Benakat Integra Tbk yang mengalami keuntungan, PT XL Axiata Tbk (EXCL) yang mengakuisisi PT Axis Telekom Indonesia mengalami penurunan ditahun 2014, kerugian ini diakibatkankarena Axis dilaporkan mengalami kerugian sebesar Rp 1,6 triliun. Jika disetahunkan (annualized), rugi bersih Axis berpotensi mencapai Rp 3,2 triliun, lebih besar dibanding estimasi laba bersih XL pada tahun 2014 sebesar Rp 1,5 triliun. Sebagai pemilik saham mayoritas, kerugian bersih Axis akan ditanggung oleh XL Oleh karena itu, XL berpotensi mengalami kerugiankarena laba bersih yang dihasilkan XL kemungkinan tidak akan mampu menyerap kerugian yang ditimbulkan Axis.

Akuisisi sendiri juga banyak dilakukan perusahaan dengan berbagai motif diantaranya motif ekonomi, strategis, sinergi, diversifikasi dan non-ekonomi. Sebagian besar motif melakukanakuisisi yaitu motif sinergi dan ekonomi. Namun selain itu juga motif diversifikasi menjadi alasan perusahaan melakukan akuisisi contohnya pada PT. Salim Ivomas yangmerupakan produsen minyak dan lemak nabati terbesar di indonesia mengakuisisi79,7\% saham PT Mentari Pertiwi Makmur dengan tujuan diversifikasi ke komoditas gula, karet, kakao, teh dan mengoptimalkan lahan perkebunan yang dimiliki oleh PT Mentari Pertiwi Makmur dengan penanaman tanaman pangan. Lainnya halnya denganPT Indospring yang mengakuisisi 99\% saham PT Sinar Indra Jaya dengan 
latarbelakang untuk menghindari risiko terjadinya piutang tak tertagih, bukan untuk meningkatkan volume penjualan atau memperbesar skala bisnis (KPPU, 2014)

Dengan adanya akuisisi diharapkan akan menghasilkan sinergi sehingga nilai perusahaan akan meningkat yang mana akhirnya dapat pula meningkatkan kinerja perusahaan. Keputusan perusahaan dalam melakukan akuisisi mempunyai pengaruh yang besar dalam memperbaiki kondisi dan kinerja perusahaan. Karena dengan bergabungnya dua atau lebih perusahaan dapat menunjang kegiatan usaha, sehingga keuntungan yang dihasilkan juga lebih besar dibandingkan jika dilakukan sendiri-sendiri. Namun demikian, akuisisi masih sering dipandang sebagai keputusan kontroversial karena memiliki dampak yang sangat dramatis dan kompleks, diantaranya biaya untuk melaksanakan akuisisi sangat mahal, dan hasilnya pun belum tentu sesuai dengan yang diharapkan.

Di bawah ini terdapat perbedaan kinerja keuangan antara sebelum dan sesudah akuisisi pada salah satu contoh perusahaan yang akan diteliti yaitu pada PT. XL AXIATA, yang tampak pada tabel berikut ini:

Tabel : Data Variabel Kinerja Keuangan Pt. XI Axiata

\begin{tabular}{|c|l|c|c|c|c|c|c|}
\hline \multirow{2}{*}{ No } & \multirow{2}{*}{ Variabel } & \multicolumn{3}{|c|}{ Sebelum } & \multicolumn{3}{c|}{ Sesudah } \\
\cline { 3 - 8 } & & $\begin{array}{c}\text { Tahun } \\
\text { ke-2 }\end{array}$ & $\begin{array}{c}\text { Tahun } \\
\text { ke-1 }\end{array}$ & $\begin{array}{c}\text { Rata - } \\
\text { Rata }\end{array}$ & $\begin{array}{c}\text { Tahun } \\
\text { ke-1 }\end{array}$ & $\begin{array}{c}\text { Tahun } \\
\text { ke-2 }\end{array}$ & $\begin{array}{c}\text { Rata - } \\
\text { Rata }\end{array}$ \\
\hline 1 & CR (X) & 0,42 & 0,74 & 0,58 & 0,64 & 0,47 & 0,55 \\
\hline 2 & TATO (X) & 0,60 & 0,53 & 0,56 & 0,39 & 0,39 & 0,39 \\
\hline 3 & ROE (\%) & $18 \%$ & $7 \%$ & $13 \%$ & $-0,20 \%$ & $2 \%$ & $2 \%$ \\
\hline 4 & DTER (\%) & $131 \%$ & $163 \%$ & $147 \%$ & $318 \%$ & $159 \%$ & $239 \%$ \\
\hline 5 & EPS & 324,34 & 121,05 & 445,39 & $-2,97$ & 37,63 & 17,33 \\
\hline
\end{tabular}

Sumber : Laporan Keuangan (data diolah)

Berdasarkan Tabel diatas dapat dilihat pada rasio likuiditas yang diukur menggunakan current ratio yang merupakan rasio kemampuan perusahaan dalam melunasi hutang lancarnya mengalami penurunan setalah melalukan akuisisi. Pada tabel menunjukan bahwa nilai rata-rata rasio current ratio pada tahun sebelum akuisisi sebesar 0,58 artinya aset lancar 0,58 kali liabilitas lancar. Sedangkan pada tahun setelah akuisisi nilai rata-rata current ratio menurun 0,03 menjadi 0,55 yang artinya aset lancar 0,55 kali liabilitas lancar.

Dalam rasio total asset turn over pada tahun sebelum akuisisi nilai rata- rata perputaran aset sebanyak 0,56 kali lalu pada tahun setelah akuisisi nilai rata-rata total asset turn over pun menurun menjadi 0,39 kali, menurun 0,17 dari tahun sebelum akuisis. Berarti dapat dikatakan bahwa perusahaan belum efisien dalam menghasilkan penjualan menggunakan seluruh aset yang dimilikinya.

Perhitungan return on equity pada tahun sebelum akuisisi, nilai rata-rata menunjukan bahwa tingkat pengembalian equitas sebesar 13\%. Kemudian pada tahun setelah akuisisi rata-rata nilai return on equity menurun menjadi hanya sebesar $2 \%$. Artinya hasil pengembalian equitas berkurang sebesar $11 \%$ dan ini menunjukan ketidakmampuan manajemen untuk memperoleh nilai return on equity. Berarti dapat dikatakan kondisi perusahaan kurang baik karena menurunnya nilai margin laba. 
Pada tahun sebelum akuisisi nilai rata-rata debt to equity ratio adalah sebesar $147 \%$. Sedangkan pada tahun setelah akuisisi nilai rata-rata debt to equity ratiosebesar $239 \%$, debt to equity ratioyang tinggi menandakan bahwa kebutuhan ekuitas sebagian besar dipenuhi dari liabilitas. Tingkat kemampuan PT. XL Axiata, Tbk dalam membayar liabilitas dengan ekuitas sendiri dari tahun sebelum akuisisi ke tahun setelah akuisisi semakin rendah, karenadebt to equity ratiomengalami peningkatan sekitar $92 \%$.

Melalui earning per share, terlihat bahwa kesejahteraan pemegang saham menurun, sehubung dengan menurunnya laba per lembar saham yang dihasilkan perusahaan. Penuruan ini cukup lumayan besar yaitu sebesar 428,06,- perlembar saham. Pada tahun sebelum akuisisi memperoleh nilai earning per share Rp. 445,39,- per lembar saham dan menurun menjadi Rp. 17,33,-- per lembar saham setelah melakukan akuisisi.

Pada tabel tersebut diatas dapat dikatakan bahwa perubahan nilai rata-rata antara sebelum dan sesudah akuisisi yang memiliki perbedaan yang cukup besar adalah pada rasio hutangnya yang dihitung dengan debt to equity ratioyang mengingkat sebesar92\% dari tahun sebelum akuisisi yang memperoleh nilai $147 \%$ dan pada tahun setelah akuisisi meningkat menjadi 239\%. Salah satu alasan tingginya nilai hutang bisa terjadi karena tingginya nilai aktivitas perusahaan. Tetapi kenyataannya tingginya rasio hutang tidak diimbangi dengan naiknya nilai rata-ratatotal asset turn over, malah sebaliknya nilai ratarata rasio aktivitas yang dihitung dengan total asset turn over mengalami penurunan sebesar $17 \%$. Dari yang sebelum akuisisi memperoleh 0,56 dan 0,39pada tahun sesudah akuisisi. Karena turunnya nilai aktivitas tersebut menyebabkan nilai pendapatannya pun menurun. Sejalan dengan nilai rasio profitabilitas yang dihitung dengan menggunakan return on equity. Nilai rata-rata return on equitysetelah akuisisi menurun sebesar $11 \%$ dari tahun sebelum akuisisi yang memperoleh nilai $13 \%$ dan $2 \%$ pada tahun setelah akuisisi. Penurunan pada nilai pendapatan juga berpengaruh terhadap penurunan nilaideviden sehinggamenyebabab nilai earning per share mengalami penurunan sebesar 428,06,- per lembar saham setelah melakukan akuisisi.Dari Tabel tersebut dapat dikatakan bahwa tingginya nilai hutang PT. XL Axiata bukan diakibatkan dari penggunaan untuk aktivitas perusahaan, tetapi tingginya nilai hutang PT. XL Axiata diakibatkan karena untuk membeli perusahaan PT. Axis pada saat akuisisi.

Ada beberapa penelitian yang meneliti tentang perbedaan kinerja keuangan perusahaan sebelum dan sesudah akuisisi namun hasil yang di dapat tidak selalu sejalan atau konsisten contohnya, seperti penelitian yang dilakukan oleh Esterlina \& Firdausy (2017) yang meneliti tentang analisis kinerja keuangan sebelum dan sesudah akuisisi. Hasil penelitian menunjukan adanya perbedaaan yang signifikan pada beberapa rasio keuangan seperti current ratio, total asset turn over, debt to equity ratio, earnings per share pada beberapa periode perbandingan. Penelitian yang sama juga dilakukan oleh Danang Bayu \& Yuniati (2016) yang meneliti kinerja keuangan pada perusahaan yang melakukan akuisisi. Hasil menunjukan bawah periode 3 tahun sebelum dan 3 tahun sesudah akuisisi pada variabel current ratio dan debt to equity ratio mempunyai perbedaan yang signifikan.

Berbeda dengan penelitian yang dilakukan oleh Kusuma \& Indahingwati (2017) yang meneliti tentang analisis perbandingan kinerja keuangan perusahaan sebelum dan sesudah akusisi pada perusahaan manufaktur.Hasil yang di peroleh berdasarkan analisis rasio yang di gunakan current ratio, total asset turnover, debt to equity ratio, dan return on equity tidak terdapat perbedaan yang signifikanSejalan dengan penelitian yang dilakukan oleh Rey Arinta (2017) yang mengatakan tidak ditemukan perbedaaan yang 
signifikan pada rasio keuangan current ratio dan debt to equity ratiosetelah melakukan akuisisi.

Berdasarkan uraikan latar belakang masalah dan perbedaan hasil - hasil penelitian sebelumnya (research gap) maka penelitian ini mengambil judul "Analisis Kinerja Keuangan Sebelum Dan Sesudah Akuisisi Pada Perusahaan YangTerdaftar Di Bursa Efek Indonesia Periode 2011-2016

\subsection{Perumusan Masalah}

Berdasarkan latar belakang tersebut di atas, maka dapat ditarik beberaparumusan masalah yang akan dijawab melalui penelitian ini adalah sebagai berikut:

1. Apakah terdapat perbedaan kinerja keuangan pada perusahaan yang terdaftar di Bursa Efek Indonesia yang diukur dengan current ratioantara sebelum dan sesudah akuisisi?

2. Apakah terdapat perbedaan kinerja keuangan pada perusahaan yang terdaftar di Bursa Efek Indonesiayang diukur dengan total aset turn over antara sebelum dan sesudah akuisisi?

3. Apakah terdapat perbedaan kinerja keuangan pada perusahaan yang terdaftar di Bursa Efek Indonesiayang diukur dengan return on equity antara sebelum dan sesudah akuisisi?

4. Apakah terdapat perbedaan kinerja keuangan pada perusahaan yang terdaftar di Bursa Efek Indonesiayang diukur dengan debt to equity ratio antara sebelum dan sesudah akuisisi?

5. Apakah terdapat perbedaan kinerja keuangan pada perusahaan yang terdaftar di Bursa Efek Indonesiayang diukur dengan earning per share antara sebelum dan sesudah akuisisi?

\section{TINJAUAN TEORITIS \\ Pengertian Akuisisi}

Akuisisi merupakan salah satu strategi eksternal yang dapat digunakan oleh perusahaan untuk melakukan ekspansi usaha tanpa harus memulai usaha dari awal. Akuisisi dapat dilakukan dengan pembelian seluruh atau sebagian dari kepemilikan suatu perusahaan. Pengertian akuisisi menurut Kamaludin dkk (2015:16) adalah upaya pengambil alihan suatu perusahaan dengan cara membeli saham mayoritas perusahaan sehingga menjadi pemegang saham pengendali tetapi dalam peristiwa akuisisi baik perusahaan yang mengambil alih ( pengakuisisi) maupun perusahaan yang diambil alih ( diakuisisi ) tetap hidup sebagai satu badan hukum yang terpisah.

Sedangkan menurut Hariyani dkk (2011:22) Akuisisi adalah Pengambilalihan perusahaan dengan cara membeli saham sebagian besar perusahaan sehingga menjadi pemegang saham pengendali. Dalam peristiwa mengambil alih suatu perusahaan, baik perusahaan yang mengakuisisi maupun perusahaan yang diakuisisi tetap hidup sebagai badan hukum yang terpisah

Kemudian menurut Sudana (2011:238) Akuisisi ialah Penggabungan dua perusahaan akuisitor membeli sebagian saham perusahaan yang di akuisisi, sehingga pengendalian manajemen perusahaan yang di akuisisi berpindah kepada perusahaan akuisitor, sementara kedua perusahaan masing-masing tetap beroperasi sebagai

suatu badan hukum yang berdiri sendiri Berdasarkan penyataan pendapatan ahli diatas dapat disimpulkan bahwa akuisisi merupakan pengambil alihan perusahaan dengan cara membeli saham perusahaan dengan tetap berdiri sebagai badan hukum sendiri dengan 
maksud untuk melakukan perluasan usaha dan meningkatkan daya saing perusahaan yang mengakuisisi maupun perusahaan yang diakuisisi.

\section{Klasifikasi Akuisisi}

Menurut Haryani dkk, (2011:25) dalam perkembangannya akuisisi ini dapat di klasifikasikan sebagai berikut:

a. Berdasarkan objek yang diambil alih, akuisisi dibagi menjadi dua, yaitu: Asset Acquisition (Akuisisi Aset), dimana Asset Acquisition merupakan suatu transaksi pembelian perusahaan untuk mendapatkan sebagaian atau seluruh aktiva perusahaan target.

Stock Acquisition (Akuisisi Saham), dimana Stock Acquisition merupakan suatu transaksi pembelian sebagian atau seluruh saham perusahaan target.

b. Berdasarkan motivasi dilakukannya akuisisi atau motif keuntungan yang ingin di raih, akuisisi dibagi menjadi dua, yaitu:

1. Financial Acquisition (Akuisisi Finansial)

Akuisisi finansial merupakan suatu tindakan akuisisi terhadap satu atau beberapa perusahaan tertentu yang dilaksanakan dengan tujuan untuk mencapai keuntungan finansial.

2. Strategic Acquisition (Akuisisi Strategis)

Akuisisi strategis merupakan suatu akuisisi yang dilaksanakan dengan tujuan untuk menciptakan sinergi dengan didasarkan pada pertimbangan- pertimbangan jangka panjang.

c. Berdasarkan aspek pemasarannya akuisisi dibagi menjadi tiga, yaitu:

1. Akuisisi dalam bentuk integrasi horisontal

Akuisisi dalam bentuk horisontal ditujukan untuk mengakuisisi pesaing langsung atau disebut "head to head competitior". Pesaing yang dimaksud dapat berupa pesaing yang memiliki produk dan jasa yang sama atau pun pesaing yang memiliki daerah pemasaran yang sama. Tindakan akuisisi ini biasanya bertujuan untuk perluasan pasar.

2. Akuisisi dalam bentuk integrasi vertikal

Akuisisi dalam bentuk vertikal ditujukan untuk menguasai mata rantai produksi dan distribusi dari hulu sampai ke hilir.

3. Akuisisi dalam bentuk konglomerasi

Akuisisi dalam bentuk konglomerasi ditujukan untuk mengakuisisi perusahaan lain yang tidak mempunyai kaitan bisnis secara langsung dengan bisnis akuisitor.

d. Berdasarkan segi lokasi antara perusahaan pengakuisisi dan perusahaan target maka akuisisi dibagi menjadi dua, yaitu:

a. Akuisisi Eksternal

Akuisisi yang terjadi antara dua atau lebih perusahaan, masing-masing dalam grup yang berbeda, atau tidak berada dalam grup yang sama.

b. Akuisisi Internal

Kebalikan akuisisi eksternal, dalam akuisisi internal perusahaanperusahaan yang melakukan akuisisi masih dalam satu grup usaha.

\section{Motif Akusisi}

Menurut Kamaludin dkk (2015:18) motif akusisi dapat dapat dilihat dari berbagai perspektif, adapun perspektif tersebut adalah sebagai berikut : 


\section{Perspektif Memaksimalkan Kekayaan Pemegang Saham}

Semua keputusan perusahaan termasuk akuisisi, dibuat dengan tujuan memaksimalkan kekayaan pemegang saham perusahaan. Hal ini berarti bahwa peningkatam cash flow yang datang dari keputusan akusisi harus memberikan nilai positif terhadap nilai bersih saat ini, Dengan akuisisi, kriteria pemaksimalan kekayaan para pemegang saham dipenuhi jika nilai tambah yang diciptakan oleh akuisisi melampaui harga akuisisi.

\section{Perspektif Ekonomi}

Akuisisi memiliki motif ekonomi yang tujuan jangka panjangnya adalah mencapai peningkatan nilai bagi perusahaan dan pemegang saham. Oleh karena itu, seluruh aktivitas dan keputusan yang diambil oleh perusahaan harus diarahkan mencapai tujuan ini. Implementasi program yang dilakukan oleh perusahaan harus melalui langkah-langkah konkrit misalnya melalui efisiensi produksi, peningkatan penjualan, pemberdayaan dan peningkatan produktivitas sumber daya manusia.

\section{Perspektif Nilai Sinergis}

Salah satu motivasi atau alasan utama perusahaan melakukan akuisisi adalah untuk menciptakan sinergi. Sinergi merupakan nilai keseluruhan perusahaan setelah akuisisi yang lebih besar daripada penjumlahan nilai masing-masing perusahaan sebelum akuisisi. Sinergi dihasilkan melalui kombinasi aktivitas secara simultan dari kekuatan atau lebih elemen perusahaan yang bergabung sedemikian rupa sehingga gabungan aktivitas tersebut dapat menghasilkan suatu efek yang lebih besar dibandingkan dengan penjumlahan aktivitas- aktivitas perusahaan jika mereka bekerja sendiri.

\section{Perspektif Diversifikasi}

Diversifikasi adalah strategi pemberagaman bisnis yang bisa dilakukan melalui akuisisi. Diversifikasi dimaksud untuk mendukung aktivitas suatu bisnis dan operasi perusahaan untuk mengamankan posisi bersaing (competitive advantage). Tujuan diversifikasi adalah untuk mendukung aktivitas bisnis dan operasi perusahaan sebagai upaya untuk mengamankan posisi bersaing. Akan tetapi jika melakukan diversifikasi yang semakin jauh dari bisnis semula, maka perusahaan tidak lagi berada dalam koridor yang mendukung kompetensi ini (core competence).

\section{Motif Non-Ekonomi}

Aktivitas akuisisi terkadang dilakukan bukan hanya untuk kepentingan ekonomi akan tetapi juga untuk kepentingan yang bersifat non ekonomi, contohnya seperti prestige dan ambition. Motif non ekonomi bisa berasal dari manajemen perusahaan atau pemilik perusahaan tersebut.

Sedangkan kinerja dimaksud dapat diukur melalui rasio-rasio keuangan. Menurut Hery (2015:142), Pada dasarnya rasio keuangan bisa dikelompokkan menjadi lima kelompok rasio yaitu: Rasio Likuiditas adalah rasio yang menunjukkan kemampuan perusahaan dalam menyelesaikan kewajiban jangka pendek yang dimiliki oleh suatu perusahaan tepat pada waktunya. Adapun rasio ini terdiri dari Rasio Lancar (Current Ratio), Rasio Cepat (Quick Ratio) dan Rasio Kas (Cash Ratio).

Rasio Aktivitas menunjukkan keefektifan sebuah perusahaan dalam menggunakan aktiva yang dimilikinya. Rasio ini terdiri dari Perputaran Aktiva (Total Asset Turn Over), Perputaran Modal Kerja (Working Capital Turn Over) Perputaran Persediaan (Inventory 
Turn Over), Perputaran Aktiva Tetap (Fixed Assets Turnover), dan Perputaran Piutang (Account Receivable Turn Over).

Rasio Profitabilitas adalah rasio yang digunakan untuk menilai seberapa efisien pengelola perusahaan dapat mencari keuntungan atau laba untuk setiap penjualan yang dilakukan. Secara umum rasio profitabilitas dalam perusahaan terdiri dari Margin Laba Kotor atas Penjualan (Gross Profit Margin), Margin Laba Operasional/Usaha atas Penjualan (Operating Profit Margin) Margin Laba Bersih atas Penjualan (Net Profit Margin), Pengembalian Aset ( Return On Assets) dan Pengembalian atas Modal Sendiri ( Return On Equity).

Rasio Solvabilitas adalah rasio yang menunjukkan kemampuan perusahaan untuk membayar seluruh kewajibannya yang didanai dengan utang. Rasio Solvabilitas terdiri dari Debt to Total Assets Ratio, Debt to Equity Ratio dan Long Term Debt to Equity, Times Interest Earned Ratio, Operating Income to Liabilities Ratio

Rasio Pertumbuhan adalah rasio untuk mengukur seberapa besar pertumbuhan prestasi yang dicapai perusahaan pada kurun waktu tertentu. Rasio pertumbuhan terdiri atas Pertumbuhan Penjualan, Pertumbuhan Aset, dan Pendapatan per Lembar Saham (Earning Per Share).

\section{METODE PENELITIAN}

\subsection{Variabel dan Pengukuran}

Variabel - variabel yang digunakan dalam penelitian ini adalah mengukur kinerja keuangan perusahaan sebelum dan sesudah akuisisi pada perusahaan yang terdaftar di Bursa Efek Indonesia ( periode 2011-2016 ) dengan menggunakan Current Ratio, Total Asset Turn Over, Return On Equity, Debt to Equity Ratio dan Earning Per Share. Adapun definisi operasional dan pengukuran adalah sebagai berikut :

\begin{tabular}{|c|c|c|}
\hline Variabel & $\begin{array}{l}\text { Definisi } \\
\text { Operasional }\end{array}$ & Formula \\
\hline $\begin{array}{l}\text { Curre } \\
\text { nt } \\
\text { Ratio }\end{array}$ & $\begin{array}{l}\text { Rasio untuk } \\
\text { mengukur seberapa } \\
\text { besar kemampuan } \\
\text { perusahaan melunasi } \\
\text { hutang lancar }\end{array}$ & $C R=\frac{\text { Aktiva Lancar }}{\text { Hutang Lancar }}$ \\
\hline $\begin{array}{l}\text { Total } \\
\text { Aset } \\
\text { Turn } \\
\text { Over }\end{array}$ & $\begin{array}{l}\text { Rasio perputaran } \\
\text { aktiva untuk } \\
\text { mengukur berapa } \\
\text { kali total aktiva } \\
\text { berputar dalam satu } \\
\text { periode }\end{array}$ & TATO $=\frac{\text { Penjualan }}{\text { Total Aktiva }}$ \\
\hline $\begin{array}{l}\text { Return } \\
\text { On } \\
\text { Equity }\end{array}$ & $\begin{array}{l}\text { Rasio untuk } \\
\text { mengukur } \\
\text { Kemampuan } \\
\text { perusahaan dalam } \\
\text { menghasilkan laba } \\
\text { dengan } \\
\text { memanfaatkan } \\
\text { modal yang }\end{array}$ & $R O E=\frac{\begin{array}{c}\text { Laba Bersih Setelah } \\
\text { Pajak }\end{array}}{\text { Ekuitas }} \times 100 \%$ \\
\hline
\end{tabular}




\begin{tabular}{|c|c|c|}
\hline & dimilikinya & \\
\hline $\begin{array}{l}\text { Debt } \\
\text { to } \\
\text { Equit } \\
y \\
\text { Ratio }\end{array}$ & $\begin{array}{l}\text { Rasio untuk } \\
\text { mengukur } \\
\text { perbandingan antara } \\
\text { hutang yang dimiliki } \\
\text { perusahaan dengan } \\
\text { modal sendiri }\end{array}$ & $D E R=\frac{\text { Total Utang }}{\text { Ekuitas }} \times 100 \%$ \\
\hline $\begin{array}{l}\text { Earning } \\
\text { Per } \\
\text { Share }\end{array}$ & $\begin{array}{l}\text { Rasio untuk } \\
\text { mengukur seberapa } \\
\text { besar kemampuan } \\
\text { perusahaan dalam } \\
\text { mempertahankan } \\
\text { dan meningkatkan } \\
\text { EPS yang telah } \\
\text { dicapai dari } \\
\text { periode ke } \\
\text { periode } \\
\text { berikutnya. }\end{array}$ & $E P S=\frac{\text { Laba Bersih }}{\text { Saham Biasa Yang Beredar }}$ \\
\hline
\end{tabular}

\subsection{Populasi dan Sampel}

\section{a. Populasi}

Dalam penelitian ini yang menjadi populasi adalah perusahaan go public yang terdaftar di Bursa Efek Indonesia (BEI) yang melakukan akuisisi pada tahun 2013 2014 berjumlah 37 perusahaan

b. Sampel

Untuk menentukan sampel yang digunakan dalam penelitian ini menggunakan teknik purposive sampling. Menurut Suliyanto (2018:226) Purposive Sampling adalah metode pemilihan sampel berdasarkan pada kriteria-kriteria tertentu. Penetuan kriteria ini ditujukan agar dapat memberikan informasi yang maksimal.

Adapun kriteria sampel secara purposive sampling dalam penelitian ini diantaranya:

Tabel : Proses Pemilihan Kriteria Sampel

\begin{tabular}{|c|l|c|}
\hline No & \multicolumn{1}{|c|}{ Kriteria } & $\begin{array}{c}\text { Jumlah } \\
\text { Perusahaan }\end{array}$ \\
\hline 1 & $\begin{array}{l}\text { Perusahaan yang terdaftar di Bursa Efek Indonesia } \\
\text { (BEI) dan melakukan akuisisi pada tahun 2013- } \\
2014\end{array}$ & 37 \\
\hline 2 & Perusahaan yang bergerak dalam sektor keuangan. & $(4)$ \\
\hline 3 & $\begin{array}{l}\text { Perusahaan yang tidak memiliki laporan keuangan } \\
\text { yang lengkap }\end{array}$ & $(7)$ \\
\hline 4 & $\begin{array}{l}\text { Perusahaan yang tidak menggunakan mata uang } \\
\text { rupiah dalam pelaporan keuangannya }\end{array}$ & $(9)$ \\
\hline 5 & $\begin{array}{l}\text { Jumlah sampel perusahaan yang memenuhi kriteria } \\
\text { penelitian }\end{array}$ & 17 \\
\hline
\end{tabular}




\subsection{Teknik Pengumpulan Data}

Adapun teknik yang dilakukan dalam penelitian ini adalah dengan menggunakan metode dokumentasi. Metode dokumentasi yaitu metode pengumpulan data yang dilakukan dengan cara mempelajari dokumen-dokumen atau data-data yang diperlukan, kemudian dilanjutkan dengan pencatatan dan perhitungan (Sugiono, 2013:24).

\subsection{Metode Analisis Data} hipotesis

Penelitian ini menggunakan Analisis Deskriptif, Uji Prasyarat, dan pengujian

\section{HASIL PENELITIAN DAN PEMBAHASAN}

\subsection{Deskripsi Data/Responden}

Deskripsi data penelitian dalam penelitian ini digunakan untuk melihat gambaran umum atau deskripsi suatu data yang dilihat dari nilai minimum, nilai maksimum, nilai mean, dan nilai standar deviasi. Berdasarkan hasil analisis data dapat dideskripsikan sebagai berikut :

Tabel : Deskriptif Data Sampel Sebelum Melakukan Akuisisi

\begin{tabular}{crrrr}
\hline Variable & Minimum & Maximum & Mean & Std. Deviation \\
\hline CR & 1,156 & 9,180 & 4,04071 & 2,120185 \\
\hline TATO &, 191 & 11,907 & 2,23165 & 2,801201 \\
\hline ROE &, 091 &, 641 &, 35212 &, 151045 \\
\hline DTER &, 310 & 6,071 & 2,22182 & 1,817139 \\
\hline EPS & 48,399 & 4307,469 & 767,85635 & 1064,853033 \\
\hline
\end{tabular}

Sumber: Data laporan keuangan yang telah diolah

a. Current Ratio sebelum melakukan akuisisi menunjukkan nilai rata-rata (mean) 4,04071 dengan nilai standar deviasi 2,120185. Mean lebih besar dari standar deviasi $(4,04071>2,120185)$ artinya distribusi data current ratio baik yaitu nilai penyimpangan data dari mean-nya lebih kecil. Sedangkan nilai minimum dan maksimum menunjukan nilai 1,156 dan 9,180.

b. Total Asset Turn Over sebelum melakukan akuisisi menunjukkan nilai rata-rata (mean) 2,23165 dengan nilai standar deviasi 2,801201. Mean lebih kecil dari standar deviasi $(2,23165<2,801201)$ artinya distribusi data total asset turn over kurang baik yaitu nilai penyimpangan data dari mean-nya lebih besar. Sedangkan nilai minimum dan maksimum menunjukan nilai 0,191 dan 11,907.

c. Return On Equity sebelum melakukan akuisisi menunjukkan nilai rata-rata (mean) 0,35212 dengan nilai standar deviasi 0,151045. Mean lebih besar dari standar deviasi $(0,35212>0,151045)$ artinya distribusi data return on equity baik yaitu nilai 
penyimpangan data dari mean-nya lebih kecil. Sedangkan nilai minimum dan maksimum return on equity menunjukan nilai 0,091 dan 0,641.

d. Debt to Equity Ratio sebelum melakukan akuisisi menunjukkan nilai rata-rata (mean) 2,22182 dengan nilai standar deviasi 1,817139. Mean lebih besar dari standar deviasi $(2,22182>1,817139)$ artinya distribusi data debt to equity ratio baik yaitu nilai penyimpangan data dari mean-nya lebih kecil. Sedangkan nilai minimum dan maksimum menunjukan nilai 0,310 dan 6,071.

e. Earning per Share sebelum melakukan akuisisi menunjukkan nilai rata-rata (mean) 767,85635 dengan nilai standar deviasi 1064,853033. Mean lebih kecil dari standar deviasi $(767,85635<1064,853033)$ artinya distribusi data earning per share kurang baik yaitu nilai penyimpangan data dari mean-nya lebih besar. Sedangkan nilai minimum dan maksimum menunjukan nilai 48,399 dan 4307,469

\section{Tabel : Deskriptif Data Sampel Sesudah Melakukan Akuisisi}

\begin{tabular}{crrrr}
\hline Variable & Minimum & Maximum & Mean & Std. Deviation \\
\hline CR & 1,115 & 17,595 & 4,54647 & 3,828165 \\
\hline TATO &, 204 & 5,999 & 1,68688 & 1,473897 \\
\hline ROE &, 016 & 1,078 &, 27747 &, 248786 \\
\hline DTER &, 159 & 4,764 & 1,78588 & 1,248341 \\
\hline EPS & 34,66 & 2431,67 & 340,6072 & 568,06442 \\
\hline
\end{tabular}

Sumber:Data laporan keuangan yang telah diolah

a. Current Ratio (CR) sesudah melakukan akuisisi menunjukkan nilai rata-rata (mean) 4,54647 dengan nilai standar deviasi 3,828165. Mean lebih besar dari standar deviasi $(4,54647>3,828165)$ artinya distribusi data current ratio baik yaitu nilai penyimpangan data dari mean-nya lebih kecil. Sedangkan nilai minimum dan maksimum menunjukan nilai 1,115 dan 17,595.

b. Total Asset Turn Over (TATO) sesudah melakukan akuisisi menunjukkan nilai ratarata (mean) 1,68688 dengan nilai standar deviasi 1,473897. Mean lebih besar dari standar deviasi $(1,68688>1,473897)$ artinya distribusi data total asset turn over baik yaitu nilai penyimpangan data dari mean-nya lebih kecil. Sedangkan nilai minimum dan maksimum menunjukan nilai 0,204 dan 5,999.

c. Return On Equity (ROE) sesudah melakukan akuisisi menunjukkan nilai rata-rata (mean) 0,27747 dengan nilai standar deviasi 0,248786. Mean lebih kecil dari standar deviasi $(0,27747>0,248786)$ artinya distribusi data return on equity baik yaitu nilai penyimpangan data dari mean-nya lebih kecil. Sedangkan nilai minimum dan maksimum return on equity menunjukan nilai 0,016 dan 1,078.

d. Debt to Equity Ratio (DTER) sebelum melakukan akuisisi menunjukkan nilai ratarata (mean) 1,78588 dengan nilai standar deviasi 1,248341. Mean lebih besar dari standar deviasi $(1,78588<1,248341)$ artinya distribusi data debt to equity ratio baik yaitu nilai penyimpangan data dari mean-nya lebih kecil. Sedangkan nilai minimum dan maksimum menunjukan nilai 0,159 dan 4,764 
e. Earning per Share (EPS) sebelum melakukan akuisisi menunjukkan nilai rata-rata (mean) 340,6072 dengan nilai standar deviasi 568,06442. Mean lebih kecil dari standar deviasi $(340,6072<568,06442)$ artinya distribusi data earning per share kurang baik yaitu nilai penyimpangan data dari mean-nya lebih besar. Sedangkan nilai minimum dan maksimum menunjukan nilai 34,66 dan 2431,67.

\subsection{Uji Instrumen/Uji Prasyarat Penelitian}

Uji normalitas digunakan untuk mengetahui distribusi data dalam variabel yang akan digunakan dalam penelitian berdistribusi normal atau tidak yang dilakukan sebelum data di olah berdasarkan model penelitian, sedangkan untuk mendeteksi normalitas data dapat dilakukan dengan menggunakan uji metode kolmogorov-smirnov test (Uji K-S). Kriteria yang digunakan, apabila signifikansi $(\alpha<5 \%)$ maka data tersebut tidak berdistribusi normal, dan sebaliknya apabila signifikansi data $(\alpha>5 \%)$ maka data tersebut berdistibusi normal (Ghozali, 2013:160)

Hipotesis nol (H0) dinyatakan bahwa dari masing-masing variabel penelitian pada periode sebelum dan sesudah akuisisi berdistribusi normal. Penentuan normal tidaknya data ditentukan apabila hasil signifikansi lebih besar dari tingkat signifikansi yang sudah ditentukan $(\alpha>0,05)$ maka H0 diterima dan data tersebut terdistribusi normal. Sebaliknya apabila signifikansi uji lebih kecil dari signifikansi yang ditentukan $(\alpha<0,05)$ maka $\mathrm{H} 0$ ditolak dan data tersebut dinyatakan tidak terdistribusi normal. Berikut ringkasan uji normalitas dengan menggunakan uji Kolmogorov Smirnov:

TABEL : Hasil Uji Normalitas One Sample Kolmogorov-Smirnov Test

\begin{tabular}{lrrc}
\hline \multicolumn{1}{c}{ Variable/Peiode } & $\begin{array}{r}\text { Kolmogorov- } \\
\text { Smirnov }\end{array}$ & $\begin{array}{r}\text { Asymp. Sig. } \\
\text { (2-tailed) }\end{array}$ & Kesimpulan \\
\hline CR Sebelum & 0,176 & 0,170 & Normal \\
CR Sesudah & 0,248 & 0,007 & Tdak Normal \\
\hline TATO Sebelum & 0,326 & 0,000 & Tidak Normal \\
TATO Sesudah & 0,211 & 0,043 & Tidak Normal \\
\hline ROE Sebelum & 0,203 & 0,061 & Normal \\
ROE Sesudah & 0,229 & 0,018 & Tidak Normal \\
\hline DTER Sebelum & 0,227 & 0,020 & Tidak Normal \\
DTER Sesudah & 0,131 & 0,200 & Normal \\
\hline EPS Sebelum & 0,250 & 0,006 & Tidak Normal \\
EPS Sesudah & 0,348 & 0,000 & Tidak Normal \\
\hline Sumber: Datalaporan
\end{tabular}

Sumber: Data laporan keuangan yang diolah

Berdasarkan hasil uji normalitas data diatas, terlihat bahwa rata-rata variabel memiliki nilai signifikansi yang lebih kecil dari taraf signifikan yang ditetapkan $(\alpha=0,05)$, dari pengujian tersebut dapat disimpulkan bahwa data sampel pada variabel-variabel tersebut tidak terdistribusi normal. Sehingga untuk menguji seluruh variabel dalam penelitian ini akan digunakan Wilcoxon Sign Rank Test. 


\subsection{Penyajian dan Analisis Data Penelitian}

Setelah diperoleh model pengujian yang sesuai terhadap data yang digunakan, maka langkah selanjutnya adalah dilakukan uji hipotesis. Pengujian hipotesis dilakukan untuk menjawab rumusan masalah dalam penelitian ini. Penelitian ini mengajukan 5 buah hipotesis. Oleh karena adanya beberapa data yang berdistribusi tidak normal, maka uji statistik yang digunakan adalah uji Wilcoxon Signed Rank Test. Kriteria pengujian dilakukan dengan menggunakan tingkat keyakinan 95\% dengan tingkat signifikansi 5\% atau nilai probabilitas asymp. sig (2-tailed) < 0,05. Berikut ini merupakan deskripsi hasil pengujian dari masing-masing hipotesis:

\section{a. Pengujian Hipotesis Pertama}

H01: Tidak terdapat perbedaan kinerja keuangan perusahaan yang diukur dengan current ratio antara sebelum dan sesudah akuisisi.

Ha1: Terdapat perbedaan kinerja keuangan perusahaan yang diukur dengan current ratio antara sebelum dan sesudah akuisisi.

Tabel : Hasil Uji Wilcoxon Signed Rank Test Pada Current Ratio Antara Sebelum dan Sesudah Akuisisi

\begin{tabular}{|ll|r|r|r|}
\hline & Ranks \\
\hline CR SESUDAH & Negative & $\mathrm{N}$ & \multicolumn{1}{c|}{$\begin{array}{c}\text { Mean } \\
\text { Rank }\end{array}$} & $\begin{array}{c}\text { Sum of } \\
\text { Ranks }\end{array}$ \\
AKUISISI - CR & Ranks & $7^{\mathrm{a}}$ & 8,57 & 60,00 \\
SEBELUM AKUISISI & Positive Ranks & $10^{\mathrm{b}}$ & 9,30 & 93,00 \\
& Ties & $0^{\mathrm{c}}$ & & \\
& Total & 17 & & \\
\hline
\end{tabular}

Tabel diatas menunjukan informasi mengenai banyaknya nilai data yang diproses. Pada kotak ranks terlihat nilai positive rank menunjukan nilai 10 , nilai ini berarti sebanyak 10 dari 17 perusahaan mengalami peningkatan pada nilai current ratio setelah akuisisi. Selanjutnya nilai negative ranks sebesar 7, nilai ini berarti sebanyak 7 dari 17 sampel perusahaan mengalami penurunan pada nilai current ratio setelah akuisisi. serta nilai ties sebesar 0 yang berarti tidak ada perusahaan yang tidak mengalami perubahan nilai pada current ratio setelah akuisisi.

\section{Test Statistics ${ }^{\mathrm{a}}$}

\begin{tabular}{|l|r|}
\hline & \multicolumn{1}{|c|}{$\begin{array}{c}\text { CR SESUDAH } \\
\text { AKUISISI - CR } \\
\text { SEBELUM AKUISISI }\end{array}$} \\
\hline $\begin{array}{l}\text { Asymp. Sig. (2- } \\
\text { tailed) }\end{array}$ &,$- 781^{\mathrm{b}}$ \\
\hline
\end{tabular}


Berdasarkan hasil test statistics uji wilcoxon signed rank test untuk current ratio yang terlihat pada tabel di atas menunjukan nilai $\mathrm{Z}$ hitung sebesar -0,781 lebih kecil dari nilai $Z$ tabel sebesar $-1,960(-0,781<-1,960)$ dan nilai .asymp. sig sebesar 0,435 . Nilai probabilitas tersebut berada di atas tingkat signifikansi sebesar $0,05(0,435>0,05)$. Hal ini menujukan bahwa $\mathrm{H}_{0}$ diterima dan $\mathrm{H}_{1}$ ditolak sehingga tidak terdapat perbedaan yang signifikan pada current ratio antara sebelum dan sesudah akuisisi.

\section{b. Pengujian Hipotesis Kedua}

H02: Tidak terdapat perbedaan kinerja keuangan perusahaan yang diukur dengan total asset turn over antara sebelum dan sesudah akuisisi.

Ha2: Terdapat perbedaan kinerja keuangan perusahaan yang diukur dengan total asset turn over antara sebelum dan sesudah akuisisi.

\section{Tabel : Hasil Uji Wilcoxon Signed Rank Test Pada Total Asset Turn Over Antara Sebelum dan Sesudah Akuisisi}

\begin{tabular}{|ll|r|r|r|}
\hline & Ranks \\
\hline TATO SESUDAH & Negative & $\mathrm{N}$ & \multicolumn{1}{c|}{$\begin{array}{c}\text { Mean } \\
\text { Rank }\end{array}$} & $\begin{array}{c}\text { Sum of } \\
\text { Ranks }\end{array}$ \\
\hline AKUISISI - TATO & Ranks & $13^{\mathrm{a}}$ & 9,08 & 118,00 \\
SEBELUM AKUISISI & Positive Ranks & $4^{\mathrm{b}}$ & 8,75 & 35,00 \\
& Ties & $0^{\mathrm{c}}$ & & \\
& Total & 17 & & \\
\hline
\end{tabular}

Tabel diatas menunjukan informasi mengenai banyaknya nilai data yang diproses. Pada kotak ranks terlihat nilai positive rank menunjukan nilai 4, nilai ini berarti sebanyak 4 dari 17 perusahaan mengalami peningkatan pada nilai total asset turn over setelah akuisisi. Selanjutnya nilai negative ranks sebesar 13, nilai ini berarti sebanyak 13 dari 17 sampel perusahaan mengalami penurunan pada nilai total asset turn over setelah akuisisi serta nilai ties sebesar 0 yang berarti tidak ada perusahaan yang tidak mengalami perubahan nilai pada total asset turn over setelah akuisisi.

Test Statistics ${ }^{\mathrm{a}}$

\begin{tabular}{|l|r|}
\hline & \multicolumn{1}{|c|}{$\begin{array}{l}\text { TATO SESUDAH } \\
\text { AKUISISI - TATO } \\
\text { SEBELUM AKUISISI }\end{array}$} \\
\hline $\begin{array}{l}\text { Asymp. Sig. (2- } \\
\text { tailed) }\end{array}$ & $-1,965^{\mathrm{b}}$ \\
\hline
\end{tabular}

Berdasarkan hasil test statistics uji wilcoxon signed rank test untuk total asset turn over yang terlihat pada tabel di atas menunjukan nilai $Z$ hitung sebesar $-1,965$ lebih besar dari nilai $Z$ tabel sebesar $-1,960(-1,965>-1,960)$ dan nilai asymp. sig sebesar 0,049. Nilai probabilitas tersebut berada di bawah tingkat signifikansi sebesar $0,05(0,049<0,05) \mathrm{Hal}$ 
ini menujukan bahwa $\mathrm{H} 02$ ditolak dan $\mathrm{Ha} 2$ diterima yang berarti terdapat perbedaan yang signifikan pada total asset turn over antara sebelum dan sesudah akuisisi.

\section{a. Pengujian Hipotesis Ketiga}

H03: Tidak terdapat perbedaan kinerja keuangan perusahaan yang diukur dengan return on equity antara sebelum dan sesudah akuisisi.

Ha3: Terdapat perbedaan kinerja keuangan perusahaan yang diukur dengan return on equity antara sebelum dan sesudah akuisisi.

\section{Tabel : Hasil Uji Wilcoxon Signed Rank Test Pada Return On Equity Antara Sebelum dan Sesudah Akuisisi}

\section{Ranks}

\begin{tabular}{|ll|r|r|r|}
\hline & & $\mathrm{N}$ & \multicolumn{1}{c|}{$\begin{array}{c}\text { Mean } \\
\text { Rank }\end{array}$} & \multicolumn{1}{c|}{$\begin{array}{c}\text { Sum of } \\
\text { Ranks }\end{array}$} \\
\hline ROE SESUDAH & Negative & $14^{\mathrm{a}}$ & 8,57 & 120,00 \\
AKUISISI - ROE & Ranks & $3^{\mathrm{b}}$ & 11,00 & 33,00 \\
SEBELUM AKUISISI & Positive Ranks & $0^{\mathrm{c}}$ & & \\
& Ties & 17 & & \\
& Total & & \\
&
\end{tabular}

Tabel diatas menunjukan informasi mengenai banyaknya nilai data yang diproses. Pada kotak ranks terlihat nilai positive rank menunjukan nilai 3, nilai ini berarti sebanyak 3 dari 17 perusahaan mengalami peningkatan pada nilai return on equity setelah akuisisi. Selanjutnya nilai negative ranks sebesar 14, nilai ini berarti sebanyak 14 dari 17 sampel perusahaan mengalami penurunan pada nilai return on equity setelah akuisisi serta nilai ties sebesar 0 yang berarti tidak ada perusahaan yang tidak mengalami perubahan nilai pada return on equity setelah akuisisi.

\begin{tabular}{|l|r|}
\multicolumn{2}{c}{ Test Statistics $^{\text {a }}$} \\
\hline & \multicolumn{1}{|c|}{ ROE SESUDAH } \\
& AKUISISI - ROE \\
& SEBELUM AKUISISI \\
\hline $\begin{array}{l}\text { Z } \\
\text { Asymp. Sig. (2- } \\
\text { tailed) }\end{array}$ & $-2,059^{\mathrm{b}}$ \\
\hline
\end{tabular}

Berdasarkan hasil test statistics uji wilcoxon signed rank test untuk return on equity yang terlihat pada tabel di atas menunjukan nilai $Z$ hitung sebesar -2,059 lebih besar dari nilai $Z$ tabel sebesar $-1,960(-2,059>-1,960)$ dengan nilai asymp. sig sebesar 0,039. Nilai probabilitas tersebut berada di bawah tingkat signifikansi sebesar $0,05(0,039<0,05)$. Hal ini menujukan bahwa $\mathrm{H} 03$ ditolak dan $\mathrm{Ha} 3$ diterima sehingga terdapat perbedaan yang signifikan pada return on equity antara sebelum dan sesudah akuisisi.

\section{b. Pengujian Hipotesis Keempat}

H04: Tidak terdapat perbedaan kinerja keuangan perusahaan yang diukur dengan debt to equity ratio antara sebelum dan sesudah akuisisi. 
Ha4: Terdapat perbedaan kinerja keuangan perusahaan yang diukur dengan debt to equity ratio antara sebelum dan sesudah akuisisi.

Tabel : Hasil Uji Wilcoxon Signed Rank Test Pada Debt to Equity Ratio Antara Sebelum dan Sesudah Akuisisi Ranks

\begin{tabular}{|ll|r|r|r|}
\hline & & $\mathrm{N}$ & \multicolumn{1}{c|}{$\begin{array}{c}\text { Mean } \\
\text { Rank }\end{array}$} & \multicolumn{1}{c|}{$\begin{array}{c}\text { Sum of } \\
\text { Ranks }\end{array}$} \\
\hline DTERSESUDAH & Negative & $8^{\mathrm{a}}$ & 9,75 & 78,00 \\
AKUISISI - DTER & Ranks & $9^{\mathrm{b}}$ & 8,33 & 75,00 \\
SEBELUM AKUISISI & Positive Ranks & $0^{\mathrm{c}}$ & & \\
& Ties & 17 & & \\
& Total & & \\
\hline
\end{tabular}

Tabel diatas menunjukan informasi mengenai banyaknya nilai data yang diproses. Pada kotak ranks terlihat nilai positive rank menunjukan nilai 9, nilai ini berarti sebanyak 9 dari 17 perusahaan mengalami peningkatan pada nilai debt to equity ratio setelah akuisisi. Selanjutnya nilai negative ranks sebesar 8, nilai ini berarti sebanyak 8 dari 17 sampel perusahaan mengalami penurunan pada nilai debt to equity ratio setelah akuisisi serta nilai ties sebesar 0 yang berarti tidak ada perusahaan yang tidak mengalami perubahan nilai pada debt to equity ratio setelah akuisisi.

\section{Test Statistics ${ }^{\text {a }}$}

\begin{tabular}{|l|r|}
\hline & \multicolumn{1}{|c|}{$\begin{array}{c}\text { DTERSESUDAH } \\
\text { AKUISISI - DTER } \\
\text { SEBELUM AKUISISI }\end{array}$} \\
\hline$Z$ &,$- 071^{\mathrm{b}}$ \\
$\begin{array}{l}\text { Asymp. Sig. (2- } \\
\text { tailed) }\end{array}$ &, 943 \\
\hline
\end{tabular}

Berdasarkan hasil test statistics uji wilcoxon signed rank test untuk debt to equity ratio yang terlihat pada tabel di atas menunjukan nilai $\mathrm{Z}$ hitung sebesar $-0,071$ lebih kecil dari nilai $Z$ tabel sebesar $-1,960(-0,071<-1,960)$ dengan nilai nilai asymp. sig sebesar 0,943 . Nilai probabilitas tersebut berada di atas tingkat signifikansi sebesar $0,05(0,943>0,05)$. Hal ini menujukan bahwa H04 diterima dan Ha4 ditolak sehingga tidak terdapat perbedaan yang signifikan pada debt to equity ratio antara sebelum dan sesudah akuisisi.

\section{c. Pengujian Hipotesis Kelima}

H05: Tidak terdapat perbedaan kinerja keuangan perusahaan yang diukur dengan earning per share antara sebelum dan sesudah akuisisi.

Ha5: Terdapat perbedaan kinerja keuangan perusahaan yang diukur dengan earning per share antara sebelum dan sesudah akuisisi. 
Tabel : Hasil Uji Wilcoxon Signed Rank Test Pada Earning Per Share Antara Sebelum dan Sesudah Akuisisi Ranks

\begin{tabular}{|ll|r|r|r|}
\hline & & $\mathrm{N}$ & \multicolumn{1}{c|}{$\begin{array}{c}\text { Mean } \\
\text { Rank }\end{array}$} & \multicolumn{1}{c|}{$\begin{array}{c}\text { Sum of } \\
\text { Ranks }\end{array}$} \\
\hline EPS SESUDAH & Negative & $11^{\mathrm{a}}$ & 10,82 & 119,00 \\
AKUISISI - EPS & Ranks & $6^{\mathrm{b}}$ & 5,67 & 34,00 \\
SEBELUM AKUISISI & Positive Ranks & $0^{\mathrm{c}}$ & & \\
& Ties & 17 & & \\
& Total & & \\
\hline
\end{tabular}

Tabel diatas menunjukan informasi mengenai banyaknya nilai data yang diproses. Pada kotak ranks terlihat nilai positive rank menunjukan nilai 6 , nilai ini berarti sebanyak 6 dari 17 perusahaan mengalami peningkatan pada nilai earning per share setelah akuisisi. Selanjutnya nilai negative ranks sebesar 11, nilai ini berarti sebanyak 11 dari 17 sampel perusahaan mengalami penurunan pada nilai earning per share setelah akuisisi serta nilai ties sebesar 0 yang berarti tidak ada perusahaan yang tidak mengalami perubahan nilai pada earning per share setelah akuisisi.

\begin{tabular}{|l|r|}
\hline \multicolumn{2}{|c|}{ Test Statistics $^{\text {a }}$} \\
\hline & $\begin{array}{c}\text { EPS SESUDAH } \\
\text { AKUISISI - EPS } \\
\text { SEBELUM AKUISISI }\end{array}$ \\
\hline $\begin{array}{l}\text { Asymp. Sig. (2- } \\
\text { tailed) }\end{array}$ & $-2,012^{\mathrm{b}}$ \\
\hline
\end{tabular}

Berdasarkan hasil test statistics uji wilcoxon signed rank test untuk earning per share yang terlihat pada tabel di atas menunjukan nilai $\mathrm{Z}$ hitung sebesar -2,012 lebih besar dari nilai $Z$ tabel sebesar -1,960 (-2,012> -1,960) dengan nilai asymp. sig sebesar 0,049. Nilai probabilitas tersebut berada di bawah tingkat signifikansi sebesar $0,05(0,044<$ 0,05). Hal ini menujukan bahwa H05 ditolak dan Ha5 diterima sehingga terdapat perbedaan yang signifikan pada earning per share antara sebelum dan sesudah akuisisi.

\subsection{Pembahasan}

\section{a. Perbedaan Current Ratio sebelum dan sesudah akuisisi}

Berdasarkan hasil uji wilcoxon dalam penelitian ini terdapat 7 perusahaan yang mengalami penurunan pada nilai current ratio setelah akuisisi yang mencerminkan kemampuan perusahaan dalam memenuhi hutang jangka pendeknya yang menurun setelah akuisisi walaupun terdapat 10 perusahan yang mengalami pengingkatan pada nilai current ratio setelah akuisisi tetapi ini tidak menjamin peningkatan tersebut meningkat secara signifikan hal tersebut dibuktikan dengan nilai $\mathrm{Z}$ hitung sebesar $-0,781$ lebih kecil dari nilai $Z$ tabel sebesar $-1,960(-0,781<-1,960)$ dan nilai probabilitas 0,435 berada di atas tingkat signifikansi sebesar $0,05(0,435>0,05)$ yang dapat disimpulkan bahwa tidak terdapat perbedaan yang signifikan antara sebelum dan sesudah akuisisi. 
Hasil penelitian ini menunjukkan bahwa tidak terdapat perbedaan signifikan pada current ratio perusahaan sebelum dan sesudah akuisisi dikarenakan berdasarkan data penelitian yang diperoleh, persebaran data hutang lancar dan aktiva lancar relatif konstan, tidak ada peningkatan atau penurunan secara signifikan pada periode sebelum dan sesudah perusahaan melakukan aktivitas akuisisi.

Seharusnya dengan dilakukan akuisisi berarti aset lancar perusahaan digabungkan, maka seharusnya kemampuan perusahaan untuk memenuhi kewajiban jangan pendeknya semakin baik, yang ditunjukan dengan adanya perbedaan yang signifikan, namun karena hasilnya tidak menunjukan adanya perbedaan yang signifikan menandakan bahwa perusahaan belum optimal dalam menggunakan aktiva lancarnya untuk melunasi utang lancar perusahaan setelah melakukan akuisisi. Ini berarti sinergi yang lebih baik yang diharapkan perusahaan setelah melakukan akuisisi tidak tercapai yang disebabkan karena hutang lancar yang lebih besar di bandingkan aktiva lancarnya. Hasil penelitian ini sejalan dengan hasil penelitian Kusuma \& Indahingwati (2017), dan Pratiwi \& Panji.S (2017) yang menyatakan bahwa tidak ada perbedaan yang signifikan pada kinerja keuangan yang diukur dengan menggunakan current ratio.

\section{b. Perbedaan Total Asset Turn Over sebelum dan sesudah akuisisi}

Berdasarkan Hasil uji wilcoxon dalam penelitian ini mendukung hipotesis kedua bahwa adanya perbedaan total asset turn over antara sebelum dan sesudah akuisisi. Hal tersebut dibuktikan dengan nilai $\mathrm{Z}$ hitung sebesar $-1,965$ lebih besar dari nilai $\mathrm{Z}$ tabel sebesar $-1,960(-1,965>-1,960)$ dengan nilai probabilitas 0,049 berada di bawah tingkat signifikansi sebesar $0,05(0,049<0,05)$ yang disimpulkan bahwa terdapat perbedaan yang signifikan antara sebelum dan sesudah akuisisi.

Adanya perbedaan yang signifikan pada kinerja keuangan yang diukur dengan menggunakan total asset turn over mengarah pada penurunan nilai rasio total asset turn over yang signifikan, 13 dari 17 total perusahaan mengalami penurunan total asset turn over. Hal ini disebabkan karena perputaran aktiva yang meningkat tidak mampu menghasilkan keuntungan yang besar dari proses penjualan yang melebihi dari total hutangnya.

Seharusnya dengan dilakukannya akuisisi, aset-aset perusahaan digabungkan, manajemen yang bergabung juga diharapkan semakin efektif dan efisien, serta kemampuan perusahaan untuk mengelola asetnya semakin baik, yang ditandai dengan adanya perbedaan signifikan pada variabel total assets turn over. Namun karena hasil menunjukan bahwa setelah akuisisi malah rata-rata perusahaan mengalami penurunan pada nilai total assets turn over, hal ini berarti proses akuisisi belum berhasil dalam menciptakan sinergi yang diharapkan. Hasil penelitian ini sejalan dengan hasil penelitian Prisya Esterlina \& Nila Nuzula Firdausi (2017) yang menyatakan bahwa terjadi penurunan yang signifikan pada kinerja keuangan yang diukur dengan menggunakan total assets turn over pada saat setelah akusisi.

\section{c. Perbedaan Return On Equity sebelum dan sesudah akuisisi}

Hasil uji wilcoxon dalam penelitian ini mendukung hipotesis keempat bahwa adanya perbedaan return on equity antara sebelum dan sesudah akuisisi. Hal tersebut dibuktikan dengan nilai $\mathrm{Z}$ hitung sebesar $\quad-2,059$ lebih besar dari nilai $\mathrm{Z}$ tabel sebesar $-1,960(-2,059>-1,960)$ dengan nilai probabilitas 0,039 berada di atas bawah signifikansi sebesar $0,05(0,039<0,05)$ yang dapat disimpulkan bahwa terdapat perbedaan yang signifikan antara sebelum dan sesudah akuisisi. 
Adanya perbedaan yang signifikan pada kinerja keuangan yang diukur dengan menggunakan return on equity mengarah pada penurunan nilai rasio return on equity yang signifikan, sebanyak 14 dari 17 total perusahaan mengalami penurunan return on equity hal ini disebabkan karena rata-rata perusahaan tidak mengalami peningkatan laba bersih yang tidak bisa mengimbangi peningkatan ekuitasnya.

Hal tersebut juga menunjukan bahwa pengembalian atas modal atau tingkat kemampuan perusahaan dalam menghasilkan laba bersih dari ekuitas atau modal yang dimiliki mengalami penurunan. Penurunan return on equity ini berarti perusahaan yang melakukan akuisisi belum sepenuhnya mampu memaksimalkan sumber daya atau ekuitas untuk mencetak profit yang besar. Hasil penelitian ini memperkuat hasil penelitain yang dilakukan oleh Indah Cahyarini (2017) yang mengatakan bahwa terdapat perbedaan yang signifikan pada tingkat profitabilitas yang diukur dengan return on equity setelah melakukan akuisisi.

\section{d. Perbedaan Debt to Equity Ratio sebelum dan sesudah akuisisi}

Hasil uji wilcoxon dalam penelitian ini tidak mendukung hipotesis kelima bahwa adanya perbedaan debt to equity ratio antara sebelum dan sesudah akuisisi. Hal tersebut dibuktikan dengan nilai $Z$ hitung sebesar $\quad-0,071$ lebih kecil dari nilai $Z$ tabel sebesar $-1,960(-0,071<-1,960)$ dengan nilai probabilitas 0,943 berada di atas tingkat signifikansi sebesar $0,05(0,943>0,05)$ yang disimpulkan bahwa tidak terdapat perbedaan yang signifikan antara sebelum dan sesudah akuisisi.

Hasil penelitian ini menunjukan 9 dari 17 perusahaan mengalami penurunan pada nilai debt to equity ratio. Penurunan debt to equity ratio pada penelitian yang di uji menggunakan wilcoxon signed rank test menunjukan sebagian perusahaan sudah optimal dalam menggunakan ekuitas yang ada untuk membayar hutang kepada kreditor setelah melakukan akuisisi tetapi karena hasil uji wilcoxon menunjukan asmp.sig 0,943 yang lebih besar dari 0,05 berarti dapat dikatakan penurunan tersebut tidak terjadi secara signifikan pada seluruh sampel penelitian.

Berdasarkan data yang diperoleh, hal ini terjadi karena total hutang dan ekuitas perusahaan cenderung konstan setiap tahunnya, tidak ada peningkatan atau penurunan secara signifikan pada periode sebelum dan sesudah akuisisi yang menunjukan sebagaian perusahaan belum optimal dalam menggunakan ekuitas yang ada untuk membayar hutang kepada kreditor setelah melalukan akuisisi. Hal ini disebabkan karena perusahaan memilih menggunakan hutang sebagai sumber pembiayaannya dan ini menandakan perusahaan tidak dapat menggunakan aktiva perusahaan yang ada secara optimal. Harusnya setelah melakukan akuisisi diharapkan perusahaan dapat mencapai sinergi yang diharapkan sehingga penggunaan hutang oleh perusahaan dapat diminimalisir.

Seharusnya dengan dilakukannya akuisisi terdapat perbedaan yang signifikan pada rasio debt to equity ratio, namun karena hasil pengujian menunjukkan bahwa tidak terdapat perbedaan yang signifikan, berarti akuisisi belum memberikan peningkatan pada kinerja perusahaan. Hasil penelitian ini sesuai dengan penelitian yang dilakukan Jannatun Firdaus \& Tri Yuniati (2016) yang mengatakan bahwa tidak terdapat perbedaan yang signifikan pada kinerja keuangan perusahaan yang diukur dengan debt to equity ratio pada sebelum dan sesudah akuisisi.

\section{e. Perbedaan Earning Per Share sebelum dan sesudah akuisisi}

Hasil uji wilcoxon dalam penelitian mendukung hipotesis kedua bahwa adanya perbedaan earning per share antara sebelum dan sesudah akuisisi. Hal tersebut dibuktikan dengan nilai $Z$ hitung sebesar -2,012 lebih besar dari nilai $Z$ tabel sebesar -1,960 (-2,012 $<-1,960)$ dengan nilai probabilitas 0,044 berada dibawah tingkat signifikansi sebesar 0,05 
$(0,044<0,05)$ yang disimpulkan bahwa terdapat perbedaan yang signifikan antara sebelum dan sesudah akuisisi.

Adanya perbedaan yang signifikan pada kinerja keuangan yang diukur dengan menggunakan earning per share mengarah pada penurunan nilai rasio earning per share yang signifikan, sebanyak 11 dari 17 total perusahaan mengalami penurunan earning per share. Penurunan yang signifikan pada rasio earning per share menunjukan bahwa tingkat rasio pasar perusahaan yang melakukan akuisisi turun atau tingkat harga sahamnya menurun. Penyebab menurunnya earning per share dikarenakan beberapa perusahaan yang memiliki laba bersih meningkat dan dibarengi dengan jumlah saham beredar mengingkat signifikan sehingga mengakibatkan penurunan nilai earning per share.

Dapat disimpulkan bahwa berdasarkan hasil uji wilcoxon sign rank test dengan dilakukannya akuisisi belum membuat perubahaan yang positif bagi perusahaan khususnya dalam harga saham yang ada, dengan kata lain harga saham menurun serta keuntungan yang diperoleh investor sahamnya menurun. Hasil penelitian ini didukung oleh penelitian sebelumnya yang dilakukan Esterlina dan Firdausi (2017) yang mengatakan bahwa earning per share mengalami penurunan yang signifikan pada saat setelah akuisisi yang disebabkan laba bersih perusahaan menurun dari tahun sebelumnnya.

Tabel : Hasil Ringkasan Uji Wilcoxon Signed Rank Test Ratio Keuangan

\begin{tabular}{|c|l|c|c|c|}
\hline No & \multicolumn{1}{|c|}{ Variabel } & Z Hitung & Asym.Sig & Kesimpulan \\
\hline 1 & Current Ratio & -0.781 & 0.435 & Tdk. Signifikan \\
\hline 2 & Total Asset Turn Over & -1.965 & 0.049 & Signifikan \\
\hline 3 & Return On Equity & -2.059 & 0.039 & Signifikan \\
\hline 4 & Debt to Equity Ratio & -0.071 & 0.943 & Tdk. Signifikan \\
\hline 5 & Earning Per Share & -2.012 & 0.044 & Signifikan \\
\hline
\end{tabular}

Berdasarkan pengujian data dengan menggunakan Wilcoxon Signed Rank Test menunjukan bahwa terdapat dua rasio keuangan yang tidak menunjukan perbedaan secara signifikan untuk periode sebelum dan sesudah akuisisi. Rasio keuangan tersebut adalah current ratio dan debt to equity ratio, hal ini ditandai dengan nilai $\mathrm{Z}$ hitung yang lebih kecil dari $\mathrm{Z}$ tabel ( $\mathrm{Z}$ hitung $<\mathrm{Z}$ tabel) dan nilai Asym. Sig yang berada diatas tingkat signifikansi sebesar 0,05 (probabilitas $>0,05$ ) Sedangkan tiga rasio keuangannya lainnya yaitu total asset turn over, return on equity, dan earning per share menunjukan adanya perbedaan yang signifikan antara sebelum dan sesudah akuisisi, hal ini ditandai dengan nilai $\mathrm{Z}$ hitung yang lebih besar dari $\mathrm{Z}$ tabel ( $\mathrm{Z}$ hitung $>\mathrm{Z}$ tabel) dan nilai Asym. Sig yang berada dibawah tingkat signifikansi sebesar 0,05 (probabilitas $<0,05$ ).

Berdasarkan hasil diatas dapat dikatakan bahwa secara umum kinerja keuangan sebelum dan sesudah akuisisi menunjukan adanya perbedaan yang artinya kebijakan akuisisi yang dilakukan mempunyai pengaruh terhadap kinerja keuangan. Walaupun perbedaan signifikan yang terjadi pada total asset turn over, return on equity, earning per share mengarah pada penurunan kinerja, hal ini menunjukan bahwa perusahaan yang menjadi target akuisisi adalah perusahaan yang kurang baik dalam arti secara financial maupun secara operasional sehingga menyebabkan perusahaan yang mengakuisisi setelah 
melakukan akuisisi tidak menjadi lebih baik tetapi penurunan yang terjadi bisa saja disebabkan oleh faktor internal yang terjadi pada perusahaan itu sendiri.

\section{SIMPULAN}

Penelitian ini bertujuan untuk mengetahui ada tidaknya perbedaan kinerja keuangan perusahaan sebelum dan sesudah akuisisi, dilihat dari rasio keuangan perusahaan yang diproksikan dengan current ratio, total assets turnover, return on equity, debt to equity ratio, dan earnings per share. Kesimpulan dari penelitian ini adalah sebagai berikut:

1. Tidak terdapat perbedaan pada current ratio antara sebelum dan sesudah akuisisi. Hal tersebut dibuktikan dengan hasil pengujian menggunakan uji wilcoxon signed rank test yang menunjukan nilai $\mathrm{Z}$ hitung sebesar -0,781 atau lebih kecil dari nilai $\mathrm{Z}$ tabel (1,960) dan nilai Asym. Sig 0,435 berada di atas tingkat signifikansi $(0,05)$. Hal ini disebabkan karena perusahaan belum optimal dalam menggunakan aktiva lancarnya untuk melunasi utang lancar perusahaan setelah melakukan akuisisi

2. Terdapat perbedaan pada total asset turn over antara sebelum dan sesudah akuisisi. Hal tersebut dibuktikan dengan hasil pengujian menggunakan uji wilcoxon signed rank test yang menunjukan nilai $\mathrm{Z}$ hitung sebesar -1,965 atau lebih besar dari nilai $\mathrm{Z}$ tabel $(-1,960)$ dan nilai Asym. Sig 0,049 berada di bawah tingkat signifikansi $(0,05)$. Namun perbedaan yang terjadi mengarah pada penurunan nilai total asset turn over yang disebabkan karena perputaran aktiva yang meningkat tidak mampu menghasilkan keuntungan yang besar dari proses penjualan yang melebihi dari total hutangnya.

3. Terdapat perbedaan pada return on equity antara sebelum dan sesudah akuisisi. Hal tersebut dibuktikan dengan hasil pengujian menggunakan uji wilcoxon signed rank test yang menunjukan nilai $\mathrm{Z}$ hitung sebesar -2,059 atau lebih besar dari nilai $\mathrm{Z}$ tabel (1,960) dan nilai Asym. Sig 0,039 berada di bawah tingkat signifikansi $(0,05)$. Namun perbedaan yang terjadi mengarah pada penurunan nilai return on equity yang disebabkan karena rata-rata perusahaan tidak mengalami peningkatan laba bersih sehingga tidak bisa mengimbangi peningkatan ekuitasnya walaupun memiliki modal yang besar tetapi perusahaan belum mampu memaksimalkan sumber dayanya untuk mencetak profit yang besar.

4. Tidak terdapat perbedaan pada debt to equity ratio antara sebelum dan sesudah akuisisi. Hal tersebut dibuktikan dengan hasil pengujian menggunakan uji wilcoxon signed rank test yang menunjukan nilai $\mathrm{Z}$ hitung sebesar -0,071 atau lebih kecil dari nilai Z tabel $(-1,960)$ dan nilai Asym. Sig 0,943 berada di atas tingkat signifikansi $(0,05)$. Hal ini disebabkan karena perusahaan memilih menggunakan hutang sebagai sumber pembiayaannya dan ini menandakan perusahaan tidak dapat menggunakan ekuitas yang ada secara optimal untuk membayar hutang.

5. Terdapat perbedaan pada earning per share antara sebelum dan sesudah akuisisi. Hal tersebut dibuktikan dengan hasil pengujian menggunakan uji wilcoxon signed rank test yang menunjukan nilai $\mathrm{Z}$ hitung sebesar -2,012 atau lebih besar dari nilai $\mathrm{Z}$ tabel (1,960) dan nilai Asym. Sig 0,044 berada di bawah tingkat signifikansi $(0,05)$. Penurunan yang terjadi pada earning per share disebabkan karena laba bersih perusahaan meningkat dan dibarengi jumlah saham beredar meningkat signifikan sehingga mengakibatkan penurunan nilai earning per share.

\section{Saran}

Beberapa saran yang dapat peneliti sampaikan berdasarkan penelitian yang telah dilakukan adalah: 
1. Bagi Investor

Investor perlu melakukan pertimbangan dalam menyikapi kegiatan akuisisi, karena belum dapat dipastikan bahwa akuisisi dapat memberikan dampak positif bagi perusahaan.

2. Bagi Penelitian Selanjutnya

Bagi Peneliti selanjutnya yang menggunakan penelitian yang sama disarankan untuk menambah jumlah sampel dan memperpanjang periode pengamatan, sehingga range data yang diolah lebih mewakilkan perbedaan yang didapat pasca perusahaan memutuskan untuk mengakuisisi perusahaan lain dan diharapkan untuk menambahkan variabel lain yang dapat digunakan untuk mengukur perbedaan kinerja keuangan perusahaan sebelum dan sesudah melakukan akuisisi

\section{REFERENSI}

Aprilianti, A. (2017). Analisis Kinerja Keuangan Perusahaan Sebelum Dan Sesudah Melakukan Transaksi Akuisisi. Journal of Chemical Information and Modeling, 53(9), 1689-1699.

Arinta, R. (2017). Perbedaan Kinerja Keuangan Perusahaan Sebelum dan Sesudah Merger/Akuisisi Yang Terdaftar di Bursa Efek Indonesia.

Cahyarini, I. (2017). Analisis Perbedaan Kinerja Keuangan Perusahaan Sebelum Dan Sesudah Merger Dan Akuisisi ( Studi Empiris Pada Perusahaan Merger Dan Pengakuisisi Yang Terdaftar Di Bursa Efek Indonesia Periode 2012-2014 ) the Difference Analysis of Financial Performance Befo. Jurnal Profita, (7), 2-14.

Dewi, Sevika. R. (2015). Analisa Perbandingan Kinerja Keuangan Beberapa Perusahaan Sebelum Dan Sesudah Akuisisi (Studi Pada Perusahaan Pengakuisisi Yang Terdaftar Di Bei Periode 2003-2013). 1-18.

Esterlina, P., \& Firdausi, N. (2017). Analisis Kinerja Keuangan Perusahaan Sebelum Dan Sesudah Merger Dan Akuisisi. Jurnal Administrasi Bisnis S1 Universitas Brawijaya, 47(2), 39-48.

Firdaus, Jannatun; Yuniati, T. (2016). Analisis Kinerja Keuangan Sebelum dan Sesudah Akuisisi Pada PT Kalbe Farma, TBK. Multiplier, 1(1), 43-56.

Ghozali, Imam. (2013). Aplikasi Multivariate Dengan Program IBM SPSS 21 Update PLS Regrasi (Edisi 7). Semarang: Badan Penerbit Universitas Diponegoro.

Hamidah, \& Noviani, M. (2013). Perbandingan Kinerja Keuangan Perusahaan Sebelum dan Sesudah Merger dan Akuisisi (Pada Perusahaan Pengakuisisi Yang Terdaftar Di Bursa Efek Indonesia Periode 2004-2006). Jurnal Riset Manajemen Sains Indonesia, 4(1), 31-52.

Hery. (2015). Analisis Kinerja Manajemen. Jakarta: PT. Grasindo.

Ikatan Akuntan Indonesia (IAI). 1999. Pernyataan Standar Akuntansi Keuangan

(PSAK) No. 22 Tahun 1999. Jakarta : Salemba Empat. 
Irawanto, D. B. (2016). Analisis Kinerja Keuangan Sebelum dan Sesudah Akuisisi PT. Bank Rakyat Indonesia TBK. 53(9), 1689-1699.

Irham, F. (2012). Analisis Kinerja Keuangan. Jakarta: Alfabeta.

Iswi Hariyani ; R. Serfianto; Cita Yustisia. (2011). Merge, Konsolidasi, Akuisisi \& Pemisahan Peusahaan. Jakarta: Visi Media.

Jumingan. (2017). Analisis Laporan Keuangan. Jakarta: PT. Bumi Aksara.

Kamaludin; Karona Cahya Susena; Berto Usman. (2015). Restrukturisasi Merger \& Akuisisi. Bandung: CV.Mandar Maju.

Kasmir. (2017). Analisis Laporan Keuangan. Jakarta: PT. Raja Grafindo Persada.

Kusuma, sigit arga; Indahingwati, A. (2017). Analisis Perbandingan Kinerja Keuangan Perusahaan Sebelum dan Sesudah Merger dan Akuisisi. Manajerial, 9(1), 31

Peraturan Pemerintah Republik Indonesia Nomor 27. 1998. Penggabungan, Peleburan dan Pengambilalihan Perseroan Terbatas. Lembaga Negara Republik Indonesia. 1998. Jakarta.Tanggal 25 Februari 2014.

Peraturan Pemerintah Nomor 57 Tahun 2010 Tentang Penggabungan atau Peleburan Badan Usaha dan Pengambilalihan Saham Perusahaan yang Dapat Mengakibatkan Terjadinya Praktik Monopoli dan Persangian Usaha Tidak Sehat ("PP 57/2010")

Pratiwi, P. \& Sedana, I. (2017). Analisis Kinerja Keuangan Perusahaan Multinasional Sebelum Dan Sesudah Akuisisi (Studi Perusahaan Multinasional Pengakuisisi Di Bei). E-Jurnal Manajemen Universitas

Putra, Sandika; Agustin, S. (2016). Analisis Perbedaan Kinerja Keuangan Sebelum Dan Sesudah Akuisisi Pada Pt Indospring Tbk. Jurnal Ilmu \& Riset Akuntansi Vol. 5 No. 12, 5(12). Retrieved from

Sujarweni, V. Wiratna (2015). Statistik Untuk Bisnis \& Ekonomi. Yogyakarta: Pustaka Baru Press

Suliyanto (2018). Metode Penelitian Bisnis untuk Skripsi, Tesis Dan Disertasi. Yogyakarta: Andi Offset.

Bekasi. 2018. "PT Bursa Efek Indonesia". http://www.idx.co.id

http://www.merdeka.com

http://www.marketeers.com 